\title{
Magnetic resonance imaging of the liver in hepatosplenic schistosomiasis mansoni
}

\author{
Ressonância magnética do fígado na forma hepatoesplênica
}

da esquistossomose mansoni

José Roberto Lambertucci ${ }^{1}$, Luciene Mota Andrade ${ }^{2}$ and Rogério Augusto Pinto-Silva ${ }^{1}$

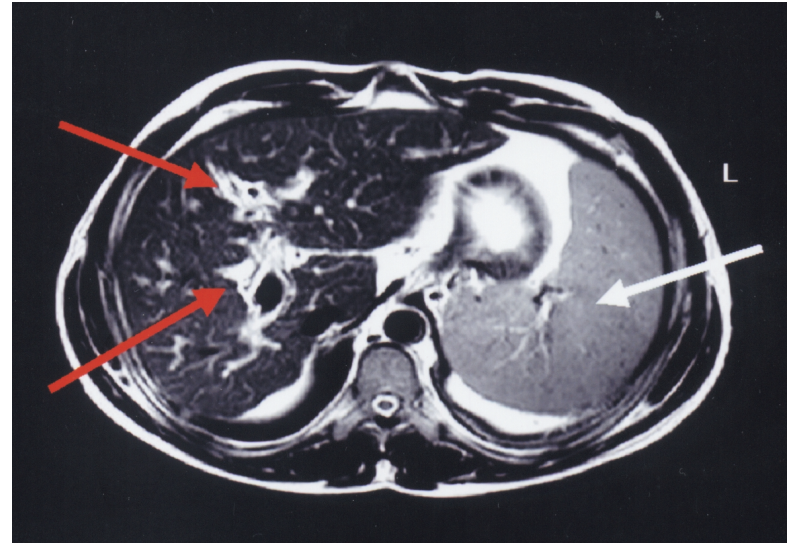

A

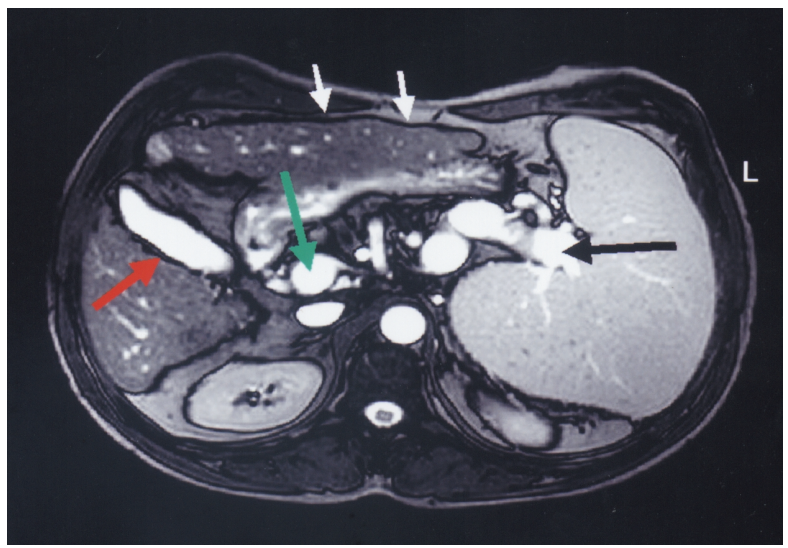

B

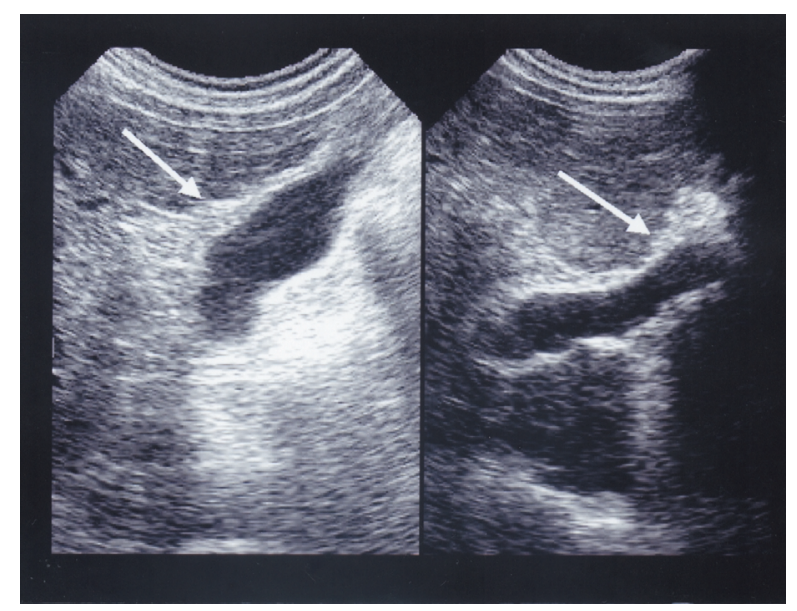

C

1. Serviço de Doenças Infecciosas e Parasitárias do Departamento de Clínica Médica da Faculdade de Medicina da Universidade Federal de Minas Gerais, Belo Horizonte, MG. 2. Laboratório Hermes Pardini, Belo Horizonte, MG.

Adress to: Dr. José Roberto Lambertucci, Deptº de Clínica Médica/FM/UFMG. Av. Alfredo Balena 190, 30130-100 Belo Horizonte, MG.

e-mail: lamber@net.em.com.br

Accepted 10 september 2002. 
A 34-year-old man, born and resident in an area endemic for schistosomiasis in the northeast of Minas Gerais state, Brazil, came to Belo Horizonte seeking medical care with a previous history of treatment for schistosomiasis and reporting a recent episode of digestive bleeding. Hepatosplenomegaly was observed during clinical examination. Endoscopy revealed esophageal varices of small and medium sizes; the presence of bleeding antral gastritis was also reported. Stool examination disclosed viable eggs of Schistosoma mansoni. An ultrasound of the abdomen showed liver alterations suggesting periportal fibrosis described in severe schistosomiasis mansoni and evidence of portal hypertension. Magnetic resonance imaging of the liver (Figure A: T2 weighted image - turbo spin echo) revealed periportal thickening appearing as a hyperintense signal (red arrows) and splenomegaly (white arrow). In Figure B, a T2 weighted image (turbo gradient echo FISP) shows the gallbladder (red arrow), splenic vein (black arrow), portal vein (green arrow) and the nodular surface of the liver (white arrows). Ultrasound of the liver depicted in Figure $\mathrm{C}$ shows the gallbladder with a thickened wall and fibrotic scars radiating into the liver (white arrow on the left side) and periportal thickening in the bifurcation of the portal vein (white arrow on the right side). Magnetic resonance imaging of the liver, as a more objective technique, may come to be the gold standard procedure for the evaluation of hepatic fibrosis in schistosomiasis mansoni.
O paciente, de 34 anos de idade, natural e residente em área endêmica de esquistossomose no nordeste de Minas Gerais, Brasil, veio a Belo Horizonte em busca de assistência médica, com história de tratamento anterior para esquistossomose mansoni e episódio recente de hemorragia digestiva. Havia hepatoesplenomegalia ao exame clínico. A endoscopia digestiva alta confirmou a presença de varizes do esôfago de pequeno e médio calibres e, no estômago, havia gastrite antral sangrante. O exame parasitológico das fezes revelou ovos de Schistosoma mansoni. Ao ultra-som de abdômen descreveram-se alterações hepáticas sugestivas de fibrose esquistossomótica e evidências de hipertensão porta. A ressonância magnética do fígado (Figura A: imagem - turbo spin echo - ponderada em T2) identificou o espessamento periportal que se revela como sinal hiperintenso (setas vermelhas) e esplenomegalia (seta branca). Na Figura B, a imagem ponderada em T2 (turbo gradient echo FISP) mostra a vesícula biliar (seta vermelha), a veia esplênica (seta preta), a veia porta (seta verde) e a superfície nodular do fígado (setas brancas). Na Figura C, o ultra-som do fígado põe em evidência a parede espessada da vesícula biliar e traves fibróticas que penetram o parênquima hepático (seta branca à esquerda). Note também o espessamento da parede da veia porta na bifurcação (seta branca à direita). A ressonância magnética do fígado, por representar método mais objetivo, pode tornar-se o padrão-ouro na avaliação da fibrose hepática da esquistossomose mansoni.

\section{REFERENCES}

1. Lambertucci JR, Gerspacher-Lara R, Pinto-Silva RA, Barbosa MM, Teixeira R, Barbosa HF, Serufo JC, Rezende DF, Drummond SC, Rayes AA. The Queixadinha Project: morbidity and control of schistosomiasis in an endemic area in the northeast of Minas Gerais, Brazil. Revista da Sociedade Brasileira de Medicina Tropical 29: 127-135, 1996.

2. Patel AS, Castilho DF, Hibbein JR, Watkins JL. Magnetic resonance imaging appearance of hepatic schistosomiasis, with ultrasound and computed tomography correlation. American Journal of Gastroenterology 88: 113-116, 1993.

3. Richter J, Domingues AL, Barata $\mathrm{CH}$, Prata AR, Lambertucci JR. Report of the second satellite symposium on ultrasound in schistosomiasis. Memórias do Instituto Oswaldo Cruz 96 (supl):151-156, 2001. 